developing after intravenous injections ?-I am, etc.,

Hove 3, Sussex.

W. A. BOURNe.

${ }_{*}^{* *}$ We have shown these three letters to Professor Alexander Haddow and Dr. F. J. C. Roe, who reply as follows:

We are grateful for the opportunity to comment on the letters you have received from Dr. J. S. G. Cox, Dr. W. A. Bourne, and Dr. R. S. Lane, all of which contain points of interest and importance. Dr. Cox draws attention to the large quantities of Imferon used in the experiment we reported (20 June, p. 1593). This is true, since the experiment was amongst the earliest we conducted, when the primary objective was to test the findings of $\mathrm{H}$. G. Richmond ${ }^{1}$ in the rat, and to extend the study to other species; this objective has been attained, and Richmond's observations abundantly confirmed.

Since that time we have completed other experiments designed to measure the tumour yield following graded doses of Imferon given by subcutaneous injection in both rats and mice. The results are expressed in the following Table.

Tumour Yield Following Subcutaneous Injection of Imferon

\begin{tabular}{|c|c|c|c|c|c|}
\hline $\begin{array}{l}\text { Dose } \\
\text { (ml.) }\end{array}$ & No. & $\begin{array}{c}\text { No. } \\
\text { of } \\
\text { Doses }\end{array}$ & $\begin{array}{l}\text { Total } \\
\text { Dose } \\
\text { (ml.) }\end{array}$ & $\begin{array}{c}\text { Total } \\
\text { Tumours } \\
\text { at Injection } \\
\text { Site }\end{array}$ & $\begin{array}{c}\text { Minimum } \\
\text { Induction } \\
\text { Period } \\
\text { (Days) }\end{array}$ \\
\hline
\end{tabular}

\begin{tabular}{|c|c|c|c|c|c|}
\hline \multicolumn{6}{|c|}{ A. In Rats (Male) } \\
\hline 1 & 30 & 30 & 30 & $\begin{array}{lr}\text { Sarcomas } & 20 \\
\text { Histio- } & \\
\text { cytomas } & 8\end{array}$ & 145 \\
\hline 0.5 & 20 & 20 & 10 & Sarcomas & 426 \\
\hline 0.05 & 20 & 64 & 3.2 & $\begin{array}{l}\text { Sarcomas } \\
\text { Fibroma }\end{array}$ & 478 \\
\hline 0.01 & 20 & 90 & 0.9 & Sarcomas & 736 \\
\hline 0.3 & 30 & 30 & ${ }_{9}^{\text {In }}$ & $\begin{array}{l}\text { Mice (Male) } \\
\begin{array}{|lr}\text { Sarcomas } & 14 \\
\text { Histio- } & \\
\text { cytomas } & 1\end{array}\end{array}$ & 182 \\
\hline 0.05 & 30 & 47 & $2 \cdot 35$ & $\begin{array}{l}\text { Sarcomas } 11 \\
\text { Fibro- } \\
\quad \text { sarcomas } 1\end{array}$ & 168 \\
\hline 0.01 & 20 & 87 & 0.87 & Nil & - \\
\hline
\end{tabular}

From these experiments it is not possible to affirm, or to deny, the existence of a threshold. But it is reasonable to conclude: (1) that tumour yield declines, as individual and total doses are reduced; and (2) that sizable yields are still evident following doses considerably less than those used in earlier experiments.

From the results obtained in animal experiment under the conditions employed it is certainly not justifiable to assume a hazard in man. Nevertheless, these results must be used as a guide to policy, and we believe this policy should be one of caution. We entirely agree with the view of Dr. Cox that the hypothetical risk involved in the clinical use of Imferon must be balanced against the benefits. We only advise that its use be restricted wherever possible to otherwise intractable cases preferably in older agegroups, and that it be not lightly administered to cases in younger age-groups (e.g. infants and young pregnant women), who do not necesarily require it.

Dr. Cox rightly regards it as probable that cancer due to Imferon would follow some type of normal distribution curve with the median approximately oze-quarter of the life span. The agent has now been in use for some 10 years, and although this is not enough to satisfy the median induction time (say 15-20 years or even more), he believes within the vast population having received the drug one would already have expected a certain incidence of tumour if the findings of animal experiment were applicable to this form of iron therapy in man. We repeat we do not know if these findings are so applicable, and only wish to impress a certain caution. We must also remember that had the results of animal experiment been entirely negative they would probably have been regarded as some evidence for safety in man.

Dr. Cox further raises the question of controls, thinking of the possible susceptibility of rabbit tissues to tumour induction by " innocuous" substances. If rather too much has perhaps been made of this argument, none the less the point must be taken in logic. The argument would apply equally to a fair part of the work on the carcinogenic hydrocarbons, when often no " controls" were employed, since it was known from experience that tumours of the types which some of these agents induce in great abundance occur spontaneously with utmost rarity. It is of interest that Richmond's discovery of the carcino- genicity of Imferon in the rat arose from his very reasonable choice of it as a control in experiments on the carcinogenicity of trypan blue for the same species.

To some extent the above comments have a bearing on the observations of Dr. R. S. Lane. However, we cannot accept the argument of a simple or direct relationship between the biological effects of a given dosage and body weight: an important factor is probably the absolute extent of local retention in whatever species.

Both Dr. Lane and Dr. Bourne raise the question of the safety or hazard of Imferon administration intravenously as compared with the intramuscular route. In 20 mice given up to four intravenous injections of $\mathbf{0 . 2}$ ml. over a period of three months two cases of adenocarcinoma of the lung have been observed, after an interval of some six months from the first injection. But we cannot as yet measure the significance of this observation (if any), since in this case comparable tumours are not unknown spontaneously. The experiments continue.-ED., B.M.f.

\section{REFERENCE}

1 Richmond, H. G., Brit. med. f., 1959, 1, 947.

\title{
Cancer in Africa
}

SIR,-It was with great interest that I read and studied the articles in the B.M.F.s of 1 and 8 February on the pattern of cancer in an African community as reported by the Kampala workers. This has prompted us to make our own analysis of histologically confirmed cases of cancer at our own hospital from 1955 to 1964. Many more cases of carcinoma occurred than the 94 cases here analysed, but in the earlier part of this period many specimens were not examined histologically and have thus been excluded.

One of the most interesting and yet most puzzling features about medicine in Africa seems to be the very large variation in the incidence of various diseases in areas which are quite close to each other and where the population is often of the same ethnic group. You will notice that there are some striking differences between our figures and those of the Kampala workers, especially in the

Analysis of Cancer Records, Mvumi Hospital, 1955-64 (As Taken From Histologically Confirmed Cases)

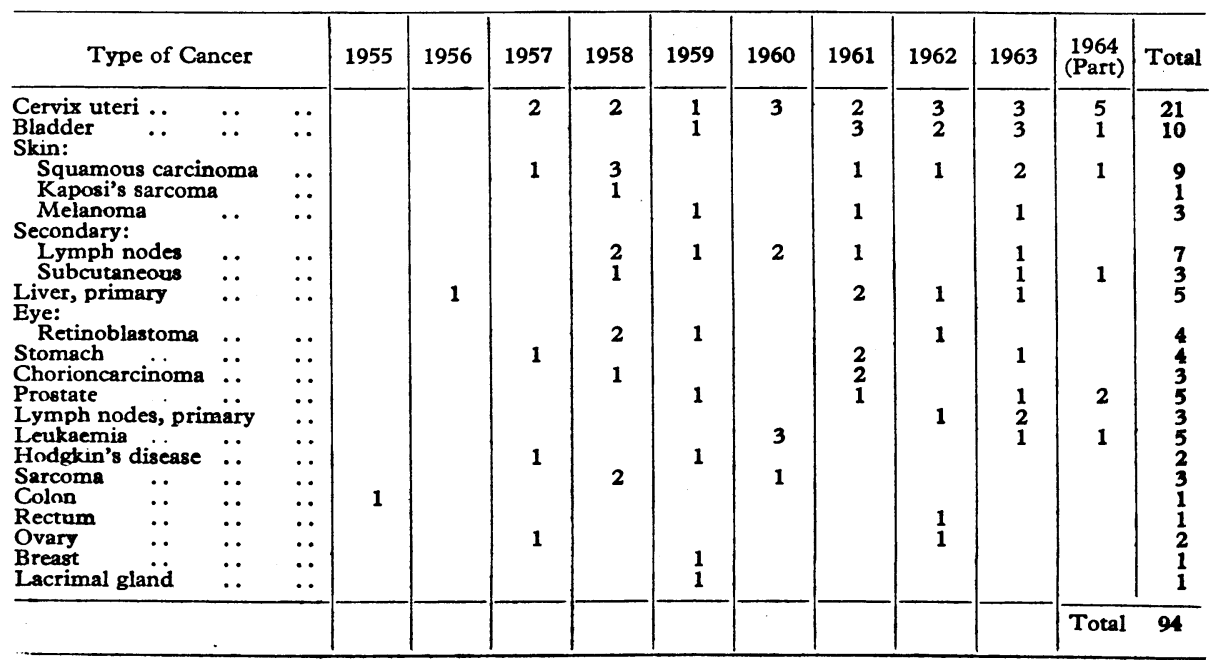
uteri is certainly one of the commonest forms of malignant disease, and in our series accounted for over $20 \%$ of the cases. This was also common in the Kampala series.

Carcinoma of the bladder was the second commonest site of cancer in our series and is also of high incidence throughout Tanganyika, though it is interesting to note that only one case is recorded in the Mengo Hospital series ; though doubtless this is due to local interests rather than difference in incidence. Whether the high incidence of carcinoma of the bladder is due to the widespread presence of bilharzia (Schistosoma haematobium) is not certain, but it is certainly suggested.

The small number of cases of primary carcinoma of the liver is not a true picture, as most of the patients were seen in out-patients whole of Tanganyika cancer of the cervix most of the patients were seen in out-patients
and then sent away. The cases recorded are 
those in which there was some doubt as to the diagnosis and laparotomy was carried out and biopsy taken.

We have noted the relatively common occurrence of carcinoma of the prostate in this region; this is not mentioned in the Kampala series, though there seems no obvious reason to account for this.

One further comment remains, and this seems to be the relatively high occurrence of chorioncarcinoma; this represents an incidence of about 1 in 500 deliveries, and though there is bound to be some selection in that only abnormal cases come to hospital there does seem to be a relatively high incidence. We have noticed a similar trend in the incidence of hydatidiform mole and it is possible that these two are interconnected.-I am, etc.,

$$
\underset{\text { Mvumi Hospital, }}{\text { Tanganyika. }}
$$

JOSEPH TAYLOR.

Tanganyika.

\section{Plasma-chloride Levels in Hyperparathyroidism}

SIR,-The report by Drs. M. R. Wills and G. K. McGowan (2 May, p. 1153) that the plasma chloride tends to be higher in hyperparathyroidism than in other hypercalcaemic states prompted us to look at our own levels of plasma chloride. All the values for plasma chloride quoted here were obtained in one laboratory under the supervision of one of us (D.W.N.), by the method of Schales and Schales, ${ }^{1}$ or more recently by the standard Autoanalyser method.

We have confirmed that there is a tendency for the plasma chloride to be above 102 $\mathrm{mEq} / \mathrm{l}$. in hyperparathyroidism, and in fact $44 \%$ of the patients with hyperparathyroidism had values of $106 \mathrm{mEq} / \mathrm{l}$. or greater (see Table). However, in an additional three

\begin{tabular}{|c|c|c|c|c|}
\hline \multirow[b]{2}{*}{ Diagnosis } & \multicolumn{3}{|c|}{ Plasma Chloride (mEq/1.) } & \multirow[b]{2}{*}{ Total } \\
\hline & $\begin{array}{c}\text { Below } \\
102\end{array}$ & $102-105$ & $\begin{array}{c}106 \text { and } \\
\text { Above }\end{array}$ & \\
\hline $\begin{array}{l}\text { Hyperpara- } \\
\text { thyroidism } \quad \cdots \\
\text { Infantile }\end{array}$ & 13 & 16 & $\begin{array}{c}23 \\
(44 \%)\end{array}$ & 52 \\
\hline $\begin{array}{l}\text { hypercalcaemia } \\
\text { Vitamin-D }\end{array}$ & 0 & 4 & 7 & 11 \\
\hline $\begin{array}{l}\text { intoxication } \\
\text { Other types of }\end{array}$ & 2 & 0 & 0 & 2 \\
\hline $\begin{array}{l}\text { hypercalcaemia } \\
\text { Renal stones } \quad .\end{array}$ & $\begin{array}{r}4 \\
32\end{array}$ & $\begin{array}{r}0 \\
48\end{array}$ & $\begin{array}{r}0 \\
20\end{array}$ & $\begin{array}{r}4 \\
100\end{array}$ \\
\hline $\begin{array}{l}\text { Unselected } \\
\text { hospital patients }\end{array}$ & 1,535 & $\begin{array}{c}619 \\
(25 \cdot 7 \%)\end{array}$ & $\begin{array}{c}252 \\
(10.5 \%)\end{array}$ & 2,406 \\
\hline
\end{tabular}

patients in whom the plasma chloride was estimated for the first time after the removal of the parathyroid adenoma, the values were 106,112 , and $105 \mathrm{mEq} / \mathrm{l}$. Moreover, 11 patients with infantile hypercalcaemia all had plasma-chloride values of $102 \mathrm{mEq} / \mathrm{l}$. or more at some time while the serum calcium was elevated, and in seven infants the plasma chloride was between 106 and $117 \mathrm{mEq} / \mathrm{l}$. Six patients with other types of hypercalcaemia did not have high levels of plasma chloride. One hundred consecutive patients with renal calculi (taken in alphabetical order from our files and not suspected of having hyperparathyroidism) were considered, and 68 had chloride values of $102 \mathrm{mEq} / 1$. or greater. We examined all the plasma-chloride values obtained in the laboratory (from unselected hospital patients, both out-patients and inpatients) over the past three months, and found that $36 \%$ were $102 \mathrm{mEq} / \mathrm{l}$. or more.

Although interesting, the fact that the plasma chloride tends to be higher than average normal values in hyperparathyroidism would not seem to be helpful in the diagnosis of this condition, since similar levels often occur in patients suffering from another type of hypercalcaemia, in patients with renal calculi, and even in routine estimations of plasma chloride.-We are, etc.,

Mary G. McGeown. Desmond W. Neill.

Royal Victoria Hospital Belfast.

REFERENCE

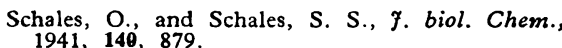

\section{Anaemia and Unexplained Blood Loss}

SIR,-Several aspects of severe, unexplained sideropenic anaemia of the elderly merit emphasis. One never fails to be astonished at their capacity to accommodate to levels of haemoglobin, even in the range of $30-40 \%$. The associated pallor simulates the skin change of age and symptoms remain in abeyance as a consequence of reduced physical activity following confinement to the home. Koilonychia and oral mucosal changes occur in both sexes. Routine chemical methods for occult blood in the faeces have usually yielded negative results in my own series; while the value of these tests is controversial $^{1-3}$ these negative findings could be attributable to intermittency of bleeding, since routinely only three consecutive specimens were examined. That recurrence following correction of the anaemia may ensue is an important realization, as exemplified by the following case.

When first seen in 1960 the patient was 70 years of age. Her haemoglobin was $47 \%(6.8$ g. per $100 \mathrm{ml}$.) and the anaemia was of irondeficiency type. Barium meal and enema were negative, as were three specimens of faeces examined for occult blood. Response to iron medication was reflected in a haemoglobin level of $102 \%$ (14.9 g. per $100 \mathrm{ml}$.) four months later. When seen in consultation four years subsequently features of cardiac failure were evident and her haemoglobin was $25 \%$ ( 3.7 g.). Transfusion was uneventful and again her anaemia was corrected with iron therapy.

-I am, etc.,

Burnley General Hospital,

J. SHAFAR.

Burnley, Lancs.

REFERENCES

Ross, G., Gray, C. H., De Silva, S., and Newman. J., Brit. med. 7., 1964, 1, 1351 . Bannerman, R. M., Beveridge, B.' R., and Witts, L. J., ibid., 1964, 1, 1417.
Lipetz, S., ibid., 1964, 1, 1638.

\section{Infectious Mononucleosis Syndromes}

SIR,-Additional cases with new findings in a syndrome resembling infectious mononucleosis after open-heart surgery, first described by Kreel et al.,' have been presented by Dr. D. R. Smith (11 April, p. 945). A similar syndrome following multiple blood transfusions for bleeding dundenal ulcer (no surgery performed) was recently observed and is described briefly.

A. B., a 31-year-old white male, was admitted to hospital on 9 September 1963 because of haematemesis, melaena, and dizziness. The pulse was 132 per minute. The liver was palpable $6 \mathrm{~cm}$. below the right costal margin. The spleen was not palpable. Emergency upper gastrointestinal $x$-ray studies revealed a duodenal ulcer. His admission haematocrit was $18 \%$. The white blood count was $19,000 /$ c.mm. with $24 \%$ lymphocytes. He was transfused with 8 units (4 litres) of whole blood (4 units fresh) and 1 unit of packed red cells $(250 \mathrm{ml}$.) during the first 24 hours following admission. The patient stabilized and there was no further evidence of bleeding.

He had a fever for the first five days and then become afebrile. The white-cell count returned to normal with a normal differential count. He was asymptomatic until the 27th day afer admission, when he developed fever up to $102.2^{\circ} \mathrm{F}$. $\left(39^{\circ} \mathrm{C}\right.$.), cervical lymphadenopathy, and splenomegaly $(4 \mathrm{~cm}$. below left costal margin). The white blood cell count was 7,000 with $70 \%$ lymphocytes, many of which were atypical and similar to those seen in virus infections or in infectious mononucleosis. The heterophil antibody test was nozative, as were blood and urine cultures. After being febrile for 16 days, he improved spontaneously without specific treatment. His entire course during the febrile period was benign.

The characteristic features of the syndrome include fever, splenomegaly, atypical lymphocytes, and lymphadenopathy usually developing three to five weeks after operations. Except for the atypical cases reported by Bergström and Dahlström, ${ }^{2}$ all cases have followed open-heart surgery. The patient described herein appears to be the first instance in which surgery was not involved. The aetiology is unknown, but most reports have suggested a virus transmitted by the transfusions. However, Petrakis and Politis ${ }^{3}$ have demonstrated the prolonged survival (up to 22 days of study) of viable mitotically competent mononuclear leucocytes in stored whole blood. Persistent mitosis of transfused leucocytes from donors with chronic myelogenous leukaemia have been detected up to 52 days after transfusion in patients with acute leukaemia by Levin et al. ${ }^{4}$ These reports suggest the possibility, as indicated by Petrakis and Politis, that this syndrome may be an example of transfusion-induced host-graft disease developing in immunologically susceptible patients. Careful follow-up immunologic and cytogenic studies of patients receiving multiple, especially fresh, wholeblood transfusions may be rewarding.-I am, etc.,

Department of Medicine, Harbor General Hospita Torrance, California, U.S.A.

\section{REFERENCES}

1 Kreel, I., Zaroff, L. I., Canter, J. W., Kranna, I., and Baronofsky, I. D., Surg. Gynec. Bergstrom. 1., and Dahlstrom, G., Acta tuberc. scand., 1957, 34, 132 .

s Petrakis, N. L ${ }^{2}$ and Politis, G., New Engl. 9. Mevin. R. H., Whang. J., Tiio, J. H., Carbone, Pcience, 1963, 142, 1305 .

\section{Steroids and Fibrinolysis}

SIR,-We were surprised to learn from the very interesting contribution of Dr. Chakrabarti and his associates (29 February, p. 534) that they found an activating effect of A.C.T.H. and corticosteroid therapy on fibrinolytic activity in patients with noninflammatory diseases since in ours as well as in other's experience corticosteroids have always produced an inhibitory action on fibrinolysis both in man and in other animals.

In recent experiments in our laboratory ${ }^{1}$ a marked inhibition of plasma fibrinolytic activity was seen after the administration of 